\title{
(Re)Encountering Walls, Tattoos, and Chickadees: Disrupting Discursive Tenacity
}

\author{
Pam Whitty, Jane Hewes, Sherry Rose, Patricia Lirette, and Lee Makovichuk
}

\begin{abstract}
Dr. Pam Whitty is a professor in the Faculty of Education at the University of New Brunswick and co-director of the Early Childhood Centre. She teaches graduate and postgraduate courses in early childhood, literacies, and critical studies. Much of her curricular and literacies work over the part 27 years has been community-based action research informed by reconceptualist early childhood perspectives. Email: whitty@unb.ca
\end{abstract}

Dr. Jane Hewes is associate dean in the Faculty of Education and Social Work at Thompson Rivers University. As co-principal investigator on the research team that wrote and developed Flight: Alberta's Early Learning and Care Framework she brings expertise in participatory research methodologies, interest in critical, postfoundational early years pedagogies, and a commitment to valuing the knowledge that childcare educators bring to professional learning.

Dr. Sherry Rose is an associate professor at the University of New Brunswick. She teaches graduate and postgraduate courses in the areas of early childhood, assessment, curriculum, critical literacies, and critical studies. She cocreates curriculum documents, materials, and workshops on a range of ECE topics, and is committed to working collaboratively with ECE educators across New Brunswick.

Dr. Patricia (Tricia) Lirette is a long-time faculty member in the Early Learning and Child Care Diploma Program at MacEwan University and currently holds the position of department chair of Human Services and Early Learning. She is co-principal investigator on the Alberta curriculum framework research team. Her other research interests include child and family policy and applying the lens of institutional ethnography to inquiry in ELCC.

Lee Makovichuk, MEd, is assistant professor with the Department of Human Services and Early Learning at MacEwan University. Her work as a co-writer and co-researcher of Flight: Alberta's Early Learning and Care Framework and pedagogical mentoring work with early childhood educators has been inspiration for her doctoral studies.

In this article, three pedagogic encounters"Encountering the Wall," "Encountering Young Tattooed Parents," and "Encountering Chickadees"-conceptualized as curricular meeting places, are theoretically reconceptualized within alternative bodies of literature. Theoretical reconceptualization revealed complexities of early childhood pedagogies and the tenacity of dominant discursive practices of developmentalism, constructed, in these instances, through age-segregated settings, parenting programs, and nature pedagogy. Theoretical reconceptualizing of these encounters worked to disrupt embodied subjugations of age-segregated children, mothers and fathers, chickadees, educators, families, and researchers.

Key words: theoretical reconceptualization; meeting place; early childhood curriculum frameworks; pedagogical documentation; discursive tenacity
In this article, we describe our processes and findings as we theoretically reconceptualize three pedagogic encounters. Working within a scholarly curriculum partnership across two Canadian universities, we initiated our joint theoretical reconceptualizing of each encounter through the idea of a meeting place. A meeting place, as conceptualized by Gunilla Dahlberg and Hillevi Lenz Taguchi (1994) and taken up by Peter Moss (2013), is theorized as "a place of encounter ... a new space for participatory democratic practice" with possibilities for "democratically co-constructing new understandings - of the child, the educator, the school, learning and knowledge" (Moss, p. 45). Each of these encounters we share with you- "Encountering the Wall," "Encountering Young Tattooed Parents," and "Encountering Chickadees"- - held significant meaning to children and adults in particular settings and programs. Each encounter was initially theorized and enacted from within early childhood literature in areas that included multi-age groupings, parental engagement, and nature pedagogy, and then reconceptualized with alternative 
bodies of literature.

\section{Theoretical reconceptualizing}

For us, theoretical reconceptualizing within and across these encounters initially centred on collections of documented artifacts that detailed each encounter. As we jointly reengaged with these collections, we moved outside pedagogical research and into literature offering possibilities for us to see differently. For example, with "Encountering the Wall"-originally a project on citizenship, we looked to political and social literature on the meaning of walls themselves; for "Encountering Young Tattooed Parents" we moved out of the parent engagement literature and into literature on the meaning of tattoos; and with "Encountering Chickadees" within the forest, we moved away from nature pedagogy for young children and into literature on common worlding. Our deliberate seeking out of other disciplinary theory worked to help us confront what we have come to call discursive tenacity-established, pervasive ways of thinking, acting, and being. In the case of these three encounters, the discursive tenacity of developmentalism can be seen with constructions of age segregation, parental engagement, and humancentric nature pedagogy for young children. With different theorizings, we came to see more clearly how particular practices worked to sustain developmental discursive practices in our everyday lives with young children, their families, the natural environment, and each other. We share these encounters and processes with you in this article.

\section{Curriculum frameworks as productive spaces}

Over the past decade, early childhood scholars within Canada have been rethinking approaches to curriculum in the early years, situating Canada within an international body of scholarship (Ashton, 2014; Hewes, Whitty, et al., 2016; Heydon \& Iannacci, 2008; Pacini-Ketchabaw, 2010; Pacini-Ketchabaw, Nxumalo, Kocher, Elliot, \& Sanchez, 2015; Pacini-Ketchabaw \& Prochner, 2013). The production and implementation of provincial early learning and child care curriculum frameworks opens critical spaces for educational debate and democratic participation. And, as Rachel Langford (2010) points out, provincial early learning curriculum frameworks have opened up new directions in early childhood care and education in Canada. While keeping in mind that pedagogical frameworks "cannot be thought of as innocent tools" (Pacini-Ketchabaw \& Pence, 2011, p. 6) we concur with Emily Ashton's thinking that "recent pan-Canadian uptake of curriculum frameworks and pedagogical documentation may incite counter possibilities and provocations with those of us working with young children" (abstract, p. 3).

For us, our work with the ongoing uptake of curriculum frameworks and pedagogical encounters across two provinces entails an ethical responsibility to contest dominant discourses (Moss, 2007). Our efforts to theoretically reconceptualize each of these encounters made it possible to confront the tenacious thinking that sustains dominant discourses in our everyday work with young children, their families, and each other. In each of these encounters we question taken-for-granted practices and reimagine other relationalities. Our hope is that these everyday examples may illuminate and inspire your practice and theorizing to think otherwise.

With "Encountering the Wall," early childhood faculty and educators took up the experimental movement of traversing and disrupting specific linguistic and material practices and their subsequent pedagogic effects. These particular effects contribute to fixing developmental identities of toddlers and 3-, 4-, and 5-year-olds. Through close observation, dialogue, and critical revisiting of pedagogic documentation, faculty and educators uncovered assumptions within pedagogic practices that act to govern multi-age experiences. As a consequence, our collective framing of very young children shifted, from "troublesome toddlers" to active agentic citizens.-

In the case of "Encountering the Wall," the wall is located within a university-based child care centre where partitions 
or walls typically divide children by age. This practice reiterates, very early in a young child's life, the long-standing developmental rationale that children reach physical, cognitive, and/or emotional milestones at certain ages and therefore derive most collective benefit from being together with similarly aged peers. Typically, walls are highly contested spaces. International walls that many of us are familiar with include the Great Wall of China, the Berlin Wall, the Israeli West Bank Barrier, and the Peace Walls of Northern Ireland (Hartwich, 2009; Major, 2011). These walls are/were the material results of political and ideological decisions, often involving previous and ongoing conflict that effectively separate peoples. As well, different encounters with these same walls often result in graffiti and art making that speak to resistance and peace (McAtackney, 2011). The wall we encounter here in the child care centre was both a dividing wall and, prior to its removal, home to creative productions of the children on either side. Although not as public as the Great Wall of China, the Berlin Wall, or the newly constructed migrant partitions that are being erected in parts of Europe, walls in child care centres have their own politics and histories.

"Encountering Young Tattooed Parents" draws on everyday practices that challenged educators' beliefs about teenage mothers, fathers, and tattoos. Theoretical reconceptualizing of this encounter centred on the affect produced by tattooed bodies and its intersections with views of particular groups of parents. Patricia MacCormack (2006) writes that "tattooed skin provokes response.... It demands engagement, whether the interlocutor is critical or celebratory of inked flesh" (p. 65). Tattoos evoke a range of contradictory meanings, calling forth images of Nazi Germany and the Holocaust, tribal cultures, the punk music scene, and gang culture. They may be associated with freedom and liberation, domination and terrorization, resistance, transgression, and belonging (Johncock, 2012; Langman, 2008; MacCormack, 2006).

Tattoos and tattooing are growing in popularity among mainstream Western youth and are often characterized as a transgressive act, or an expression of individual independence and self-identity, or "a way of claiming agency to resist domination" (Langman, 2008, p. 657). Sonja Modesti (2008) claims "tattoos can be a disconcerting performance of ferocity, can signify conscientious radical self-definition, may signify sexual independence for women, and ultimately help people reclaim their physical bodies" (p. 202). MacCormack (2006) argues that through tattooing, the "silenced" female body can "speak itself," talking back to normative notions of the female body as defined by lack (pp. 66-67).

In deepening the meaning of tattooing with this particular group of young mothers and fathers, we are drawn to theories that reach beyond the expression of individual agency toward the idea that tattooing is a "concurrent individual and social co-constitution" (Johncock, 2012, p. 241). The body is a canvas for young people to "do identity," and the act of tattooing is a "performative narrative" that embodies a story (Modesti, 2008, p. 209). Will Johncock (2012, p. 242) challenges us to think beyond binary classifications of body modifications as natural or denaturalizing and to rethink tattooing as "inherently natural," part of the "fluidity" of being bodied in the postmodern world. Taken together, these notions open a space for listening differently to tattoos.

"Encountering Chickadees" materialized from theoretical reconceptualizing of a classroom nature journal alongside a series of chickadee-child documentations. This particular encountering aims to imagine pedagogic shifts from humancentric thinking toward common worlds thinking. We draw on the work of Affrica Taylor and Veronica Pacini-Ketchabaw (2015) in their articulation of moving toward a common world pedagogy of multispecies. These authors, working with/from Donna Haraway (1997, 2008) and others (Bennett, 2010; Rose, 2011; Rose et al., 2012), name the Anthropocene as a moment of pedagogical opportunity. This transformational opportunity disrupts pedagogy as usual (p. 4), creating a space where we can reimagine what it means to be human, including rethinking agency and reenvisioning children's, adults', and more-than-human relations with/ in the world. Reimaging our complex interspecies relationships is critical at this particular moment, in part due to 
the irreversible impacts humans have had and are having on the earth (Nxumalo, 2016).

In reconceptualizing this encounter, we consider constraints of humancentric practices, and possibilities of learning from a more-than-human perspective. Doing so shifts the gaze of early childhood pedagogy from a preoccupation with individualized humancentric learning, resituating children and ourselves back within ethically entangled interspecies common worlds. In this encounter, we investigate with children how our lives are already entangled with other species, including the black-capped chickadee, and the university forest. What does it mean to embrace the common worlding as a pedagogical opportunity within the processes of pedagogical documentation? How is it possible to decentre the human when human watching and human doing is inherent to early childhood pedagogic documentation? How can we as educators rethink our learning relationships with other species, including our ethical interspecies and intergenerational responsibilities?

In each of these encounters, we strive to demonstrate how invigorating localized curriculum productions and participations, and troubling dominating discourses that govern educational relationships, helps us collectively to shift our pedagogic gazes (Foucault, 1991). Our intent is to make way for reimagining childhoods, relationships, and learning in our daily work, recognizing that our representations are partial and contestable and our responsibilities to one another are always transforming.

\section{"Encountering the Wall"}

Walls can be both positive and negative entities: they allow communities to maintain their identity and security but they also produce self-containment and isolation that deny multi-perspectives and acknowledgment of shared and parallel narratives. (McAtackney, 2011, p. 95)

\section{Setting}

The child care centre at Grant MacEwan University was established as a demonstration school in 1970 by a group of women advocating for a qualified early childhood workforce. The centre was conceived and continues to operate as a year-round, full-day child care centre for children 19 months to 5 years. Early childhood educators at the centre are active participants in teaching and learning in the two-year early learning and child care (ELCC) diploma program. The centre is recognized as a place of pedagogical leadership and innovation in the broader community. University demonstration schools are positioned as meeting places where children, their families, educators, and early childhood faculty have multiple opportunities to question particular pedagogic theories and practices. As Langford and her colleague Aurelia Di Santo (2013) note, "early learning lab [demonstration] schools play a unique role-educating and caring for young children, mentoring early childhood education students, engaging in innovative curricula practices, and participating in research" (p. 1).

\section{Provocation}

In 2005, a study tour to Reggio Emilia, Italy, provoked faculty and educators at Grant MacEwan University to critically question children's democratic participation. This shift in our thinking produced new opportunities for collective experimentation. "Encountering the Wall" emerged from a series of diverse explorations of the image of the child as citizen ( Lirette, Grove, \& MacDonald, 2014). We undertook to open a "dividing" wall between a toddler room and a classroom for 3-, 4-, and 5-year-olds. Removing the wall resulted in many "multi-age moments" (Edwards, Blaise, \& Hammer, 2009, p. 59). We witnessed children's expanding participation and relationships with space, materials, and people. Although multi-age grouping has a long history in early childhood education, it is rarely enacted in child care. Grouping by age is a developmental/industrial practice built into most licensing regulations in North America, assumed to be a "best practice" and rarely questioned (Corson, 2005). Research on 
multi-age grouping tends to recount benefits based on a developmental framing of children's social interactions, citing gains in cognitive, language, and social development (increases in sharing, turn taking and self-regulation) in multi-age classrooms (see Logue, 2006). For example, educators in one study "understood multi-age grouping as supporting children's learning, assisting children in management of peer group relations and reducing the stress associated with working in chronological groupings" (Edwards et al., 2009, p. 61).

The action of opening the wall between the two rooms provoked difficult conversations among the children's educators, faculty, and families. Multiple perspectives and dissenting voices resonated within our meeting place. We experienced an ongoing embodied struggle to avoid predicting the children's reactions beforehand (Olsson, 2009 , p. 14). For example, both faculty and educators were concerned that the larger space might be dangerous for toddlers. Would toddlers feel lost in this space? Would families be concerned about safety and lack of individual attention in a larger space and a mixed-age group? Another perceived challenge was that "unruly" toddlers might knock over play creations or run through carefully created play spaces of the 3-, 4-, and 5-year-olds. How do we reconceptualize space-beyond the traditional structures of same-aged relationships and normative ageist constructions of education and childhood (Lenz Taguchi, 2010)?

As we continued to question how walls and spaces normed our pedagogical practices and constructions of children, we invited families into the conversation. We started to look more closely at how children explore and represent their agency in/through daily experiences in their families and early childhood communities. We troubled the notion of citizenship as an end product, shifting toward a notion of citizenship as a continuous process of becoming in the here and now (Jans, 2007). With insights from families and our previous work on children's participation, we reimagined the possibilities of the new space, coming to recognize our actions as political, embedded in what Dorothy Smith (1987) names as "relations of ruling." Anne Grove, a lead educator in "Encountering the Wall," recognized that "how we gather and group children is a political act." With the wall open, children were actively negotiating the complexities of living with/in this multi-aged community. The politics had changed.

For example, as the toddlers flooded into the room for 3-, 4-, and 5-year-olds, they were motivated and intrigued by the new space, where they had access to different materials and daily rituals, like the morning meeting. At first, the toddlers watched the morning meetings from the comfort of their own room, often lining chairs up along the now invisible border between the classes. Educators paused to observe this response and intentionally waited to see what would happen. After a couple of days, the toddlers took their chairs off the previously walled border, acting with agency and self-determination, and arrived at meetings ready to contribute, expecting the right to participate in classroom decision making.

Through our pedagogical conversations, we, as educators and faculty, gained new awareness of the limitations of age-segregated classrooms and how we contributed to a particular image of toddlers as less able and, conversely, an image of the 3-, 4-, and 5-year-olds as more able. We could see "the wall" as a governing and disciplinary tool (Foucault, 1991), disciplining children and adults alike (Fendler, 2001). We could now recognize how walls classify, normalize, exclude, and surveil (Gore, 1998).

\section{Pedagogical narration: Movement and experimentation}

Encountering the wall through pedagogical narration processes, faculty and educators uncovered assumptions and opened up alternative readings of children's peer group relations. Gilles Deleuze and Félix Guattari (1987) frame children's growth as occurring congruently across a series of domains as an irregular, diverse, and everchanging process. Instead of envisioning development as constantly moving forward and upward, educators and faculty observed the 3-, 4-, and 5-year-olds going "back" to the toddler classroom space to revisit/play in a way that 
reframed their former experiences:

Younger children reminded older children of the sensory joys of water and sand, and older children returned to their past. "This is where I came from," is how they describe the Toddler Room. "I used to be here, now I am there." (Makovichuk, Hewes, Lirette, \& Thomas, 2014, p. 27)

Educators were intrigued by how the open wall revealed this historical and relational dynamic, and were confronted by their assumptions that the toddler space would hold no further challenges for the 3-, 4-, and 5-year-olds. This "experiment in movement" (Olsson, 2009) provided educators, faculty, and families with deeper views of children and childhood. We observed how the children worked to "learn about the complexities of acting on diverse ideas and perspectives in a democratic environment" (MacNaughton \& Smith, 2008, p. 40). What became apparent was the messiness and complexity inherent in children's agentic subjectivities. Educators discussed the ongoing tensions involved for children expressing themselves and considering the ideas of others. This story remains full of possibilities, continuing to challenge traditional notions and normative practices as we rethink space, place, curriculum, and democratic participation.

\section{"Encountering Young Tattooed Parents"}

Listening to parents, we learn we cannot construct an image of the child without an image of the parent. It is not possible to respect the child without respecting the parent. The reciprocal negotiation with parents, however, is a risky adventure, as we expose some of our dearest assumptions to questioning. (Vandenbroeck, De Stercke, \& Gobeyn, 2013, p. 191)

\section{Setting}

"Encountering Young Tattooed Parents" is based on pedagogic encounters that took place over several months in a community-based child care centre, one of four programs participating in action research projects (MacNaughton \& Hughes, 2008) to develop the Alberta provincial curriculum framework. One of the curriculum framework co-authors (Lee Makovichuk) was on site regularly documenting curriculum making in action with educators. Working alongside educators in a community child care centre raised many questions about family participation. How did we hear families' perspectives-their hopes, desires, and dreams for their children? How did we find meaning in these perspectives for our everyday interactions with young children?

\section{Provocation}

During a weekly planning meeting. Jody and Meghan (educators) and Lee Makovichuk (curriculum coauthor) were discussing observations of a student educator who had been calling out children's names from across the playroom to get their attention. Reflecting on this episode provoked the action to consider the power of a child's name and the story of how their name came to be. Several months later, in a new team, Jody and Katelyn documented their inquiry into families' stories of naming their children. Jody first talked with parents and then invited them to write down their stories. Jody's desire to learn the children's name stories positioned the families in a place of knowing, with Jody as a learner. This shift to parent as knower is significant. While many educators may desire equitable relationships with families, pervasive underlying discourses frame parents and parental knowledge as inadequate (Hughes \& MacNaughton, 2000). These discursive assumptions operate as a regime of truth, limiting opportunities and underestimating families' desire to participate. Such embedded assumptions also act as a barrier to the rich "funds of knowledge" that families carry (Moll, Amanti, Neff, \& Gonzalez, 1992). Jody's learning from the families disrupts prevailing discourses of "parent as spectator" (Vandenbroek \& Peeters, 2014) and "parent as other" who possesses less important knowledge of the child (Hughes \& MacNaughton, 2000). 
One mother wrote about her treasured relationships with family members, now deceased, whose names were merged to form her daughter's name:

I finally thought of Ilyanna Mae Rose.... Ilyanna is a mix between my dad lan and my little sister lana, Mae is my late sister's middle name, she meant a lot to me, and Rose is after my middle name.

Another mother wrote an eloquent three-page story about naming her child. Jody recalls encouraging the mother to pursue her writing, asking if her teachers recognized her talent for the written word. A third mother shared a tattooed poem - a promise to her infant daughter (see Figure 1).

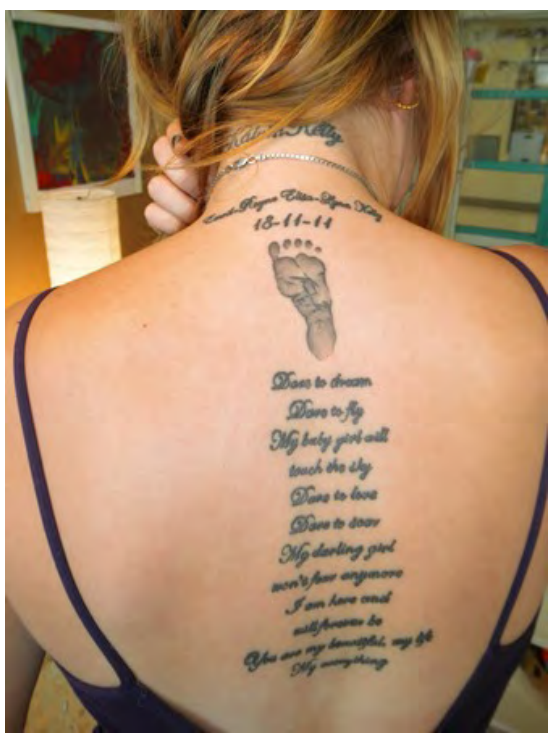

Figure 1. Tattooed promise.
Dare to dream

Dare to fly

My baby girl will

Touch the sky

Dare to love

Dare to soar

My baby girl

Won't fear anymore

I am here and will forever be

You are my beautiful, my life

My everything

\section{Pedagogical narration: The richness of family stories}

Photos of tattoos and written narratives of the children's name stories, contributed by both mothers and fathers, produced pedagogical narration that reveals the relationships forming between the educators, the children, and parents. For Jody, these stories and tattoos helped her to see the deeply felt relationships that these parents have with their children. Through this storytelling and retelling, Jody created narration that highlighted her learning of/ from the mothers and fathers, many of whom revealed body tattoos representing their deep emotional connections to their child.

Jody works in a program that provides child care for the infants and toddlers of teen parents attending high school. This program is surrounded by discourses of parent education that focus on the "good" parent. These discourses construct teen families as vulnerable, at risk, and shameful (Shoveller \& Johnson, 2006) and often lead to the subordination of parental knowledge to expert professional knowledge. As noted earlier, the result is that parental knowledge is viewed as inadequate, supplemental, and unimportant (Vandenbroek \& Peeters, 2014; Hughes \& MacNaughton, 2000).

Through close listening and revisiting pedagogical narrations of children's name stories, Jody developed deeper respect for the young parents and their use of body art, disrupting her assumptions about tattoos. This opportunity to coconstruct curriculum with children and families made visible beliefs that are often invisible yet guide our 
practice and interactions with children and families (Dahlberg, Moss, \& Pence, 2007). Jody's desire to learn about the children's name stories values aspects of a child's life that only a parent knows, and in this encounter led to more meaningful opportunities for families to participate.

Through pedagogical narrations, Jody and these young mothers and fathers made visible a strong image of young parents. What transpired was surprising and unexpected, and strengthened relationships between the educators and these young families. Jody noted that the trust cultivated through the name project has been helpful in resolving day-to-day issues that arise in the care of young children. The pedagogic work continues, as educators research the history of tattoos across cultures and question their practices. How do we respond when family perspectives challenge our professional knowledge and values? How might pedagogical narrations open a meeting place with families about things that matter to them?

\section{"Encountering Chickadees"}

We cannot maintain an open, dynamic practice without further theoretical insights; neither can we create theories without extending them through moments of practice. (Pacini-Ketchabaw et al., 2015, p. 6)

\section{Setting}

The Children's Centre in the Faculty of Education at the University of New Brunswick was established in 1974. Over these past forty years, pedagogical work at this site has contributed to provincial policy, curriculum, and family literacy programs. Family-educator relationships have been a fundamental part of the centre's work. Early childhood educators from universities, community college programs, child care centres, and schools visit this demonstration site. The educators and professors together have a long-standing history of critical reflection and complexifying early childhood pedagogies (Pacini-Ketchabaw et al., 2015) through video and photo narrations of pedagogic encounters. This space was designed strategically so that we work across the hall and around the corner from each other. Throughout any one-year period, hundreds of conversations take place between the classroom educators and the early childhood professors.

\section{Provocation}

"Encountering Chickadees" became a theoretical meeting place as we revisited documented pedagogical documentations of child-chickadee relations. In revisiting these documented encounters, many of which were included in The Classroom Nature Journal, we were provoked to think with common worlds theorizing and to think against oversimplified romantic linkages between childhood and nature (Taylor, 2013). Inspired by Taylor and Pacini-Ketchabaw (2015), we consider how we can "deliberately reposition children (and ourselves) within the full, heterogeneous and interdependent multispecies common worlds in which we all live" (p. 507). Living in a world fundamentally changed by human behaviour, we are faced with interspecies and intergenerational challenges that call us to shift from human dominance and act with relational and environmental ethics.

As Taylor and Pacini-Ketchabaw (2015) elegantly theorize, common worlds thinking and pedagogies can take us beyond the social or exclusively human, helping us to think critically about dominant discourses in early childhood. To work with this theoretical meeting place, we were guided by three questions from Taylor and Pacini-Ketchabaw (2015): What possibilities reside in the different forms of relating and intersecting within multispecies encounters? How are we deepening the curiosities that children articulate in their actions through science, histories, and biographies? And how are we enacting a caring obligation (Puig de la Bellacasa, 2010, as cited in Taylor \& PaciniKetchabaw, 2015)? In this work, we move across a range of texts, including partial narrations with photographs, 
video clips, related prior experiences, pedagogic conversations, questions and reflections within The Classroom Nature Journal, and common worlds theorizing.

The children and educators in this faculty-based program for young children regularly visit a small wooded area centrally located on the university grounds. These woods, and the university itself, sit on the traditional lands of the Wolustoquy people, yet no cultural markers of these shared and troubled colonial histories and their entanglements are visible to children, educators, faculty, or anyone who visits this land and the occupying university buildings. This lack of representation continues to erase shared colonial histories of settlers and Indigenous peoples.

\section{Pedagogical narration: Complexifying what we know}

Each time the children visit this piece of retained woods in the midst of university buildings and parking lots, they encounter and feed handfuls of seeds to black-capped chickadees and squirrels. Typically, chickadees frequent a bird feeder or perch on a child's patiently held out hand for a sunflower seed treat. Educators and children, together, observe the chickadees with quiet delight. In the process of creating multiple documentations, the educators enthusiastically document a child patiently sitting still long enough for a chickadee to land on her palm. The documentation highlights the child's capacity to control her body, and her quiet joyful concentration as a black-capped chickadee landed to feed from her fingertips. The child's desire to connect with the bird is evident. What is less evident are the long-lived theories and practices in early childhood education that link innocent child to innocent nature, what Taylor (2013) names as a romantic coupling, one that holds in place habitual enactments of humanistic pedagogies. The taming of the child's body as she awaits the chickadees-trusting or risking her body as a human perch-is palpable in conversations that surround the documentation.

In another instance, a boy draws the flight path of a chickadee as he observes them flitting down from the treetops and up from the bird feeder. An educator scribes words that appear to match both his gestures and drawing: "The chickadees fly to the sky and down to the seeds." His drawing, paired with photographs taken of the chickadee and of him at the feeder observing the little black-capped birds are placed in the classroom's nature journal. In this journal children's ordinary, everyday outdoor discoveries, observations, and experimentations are documented. Through documentation the educators acknowledge the children's intense curiosities about chickadee flight and feeding.

Educators use The Classroom Nature Journal to carefully detail children's first-hand encounters in the woods (see Figure 2). Chickadees join with pill bugs, centipedes, inchworms, dandelions, violets, lilies of the valley, tree rubbings of insect tunnels, slug tracings on paper, sketches and photos of caterpillars, chipmunks, squirrels, and scat of various animals. The journal reads beautifully as a respectful, child-centred document honouring children's observations, sketches, transcribed dialogues, and theories about the flora, fauna, and creatures that they come across. Children, families, and educators delight in these documentations that detail children's relationships within the woods and their created symbolic representations of these relations.

These tellings are delightful and we delight in them ourselves; however, we realize, as with any telling, they remain partial. In their partiality, chickadee biographies, for example, are biographies in the interest of serving the children's learning in the moment. In an effort to shift ourselves into com-

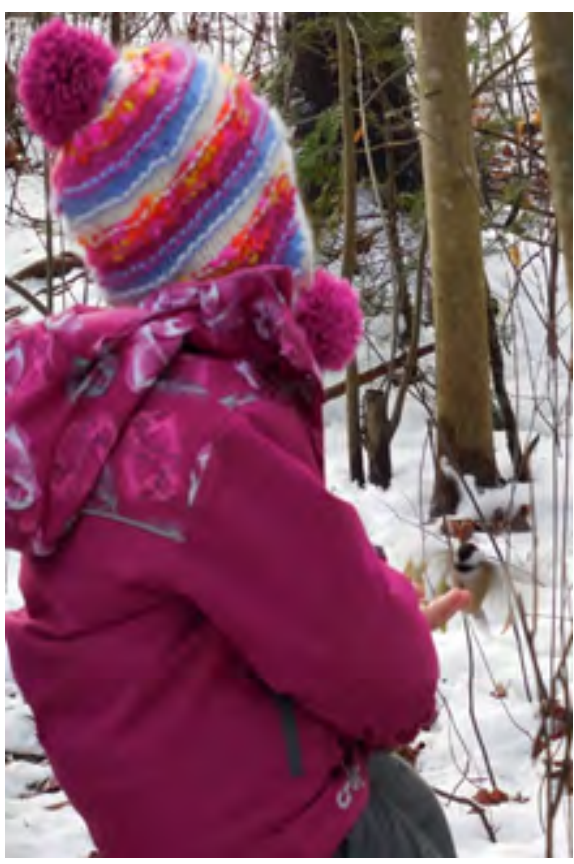

Figure 2. "In the woods" image from nature journal. 
mon world thinking, we ask what narratives remain to be told that situate children, and ourselves, alongside "earth others as respectful, related guardians and caretakers" (Ritchie, 2012, p. 86). How can we work to include the biographies and histories of the woods chickadees prior, during, and after children's encounters? What might doing so mean for the children, and for us as teacher-educators?

Keeping these questions in mind and working between common worlding and children's curiosities as they emerge in this case, we ask, where is the biography of the black-capped chickadee? What are children's impacts on the chickadees and the chickadees' effects on the children? What habitats are necessary for chickadees to flourish? What impacts have people had on chickadee habitats? What are the vulnerabilities of chickadees? What historic relationships exist between the Wolustoquy peoples, the chickadees, the woods, and settlers? With these common world questions in mind, we encouraged the educators to invite a scientist and a First Nations Elder into the woods.

Prior to the visit of the forest bird ecologist, the children generated a list of questions. When the chickadees don't eat our seeds, what do they eat? Where do they live? Do bears hunt chickadees? Do they get food at nighttime? How many eggs do chickadees have? How long do chickadee babies stay with their mom? How do they fly? Do dad chickadees look after the babies too? Tony Diamond, the forest bird ecologist, was passionate about chickadee biographies. He explained that chickadees can hide and remember 1,000 different places where they put their seeds, that a mother can carry half her weight in eggs before she lays them, that chickadee eggs are white with red dots, that chickadees usually lay 6 to 8 eggs in a nest, and that the dad chickadee helps with caring for the eggs and the babies.

When the university Elder-in-residence came with us to the woods, she introduced herself as Nuhkomos, meaning grandmother in Wolustoquy. Prior to entering the woods, she stopped momentarily to ask permission to enter. This was her first teaching for us-a deep respect for the forest as a living companion, and one we must respect as we enter. She explained that when we are sad we could tell our troubles to the trees spirits. She spoke of the two-legged, four-legged, and winged and water ones with whom we share the forest. As we sat on the forest floor, Nuhkomos spoke about the significance of each carefully selected natural object she had brought to the forest with her: hides, shells, basket, drums, and clothing made from various animals' skins, such as the fox-her family clan. Each of these items carried deep symbolic meaning. She described how hunters say a prayer and thank the animals for their gifts of hide, meat, medicine, and bones. The Elder shared her medicine bag, explaining the uses of muskrat root, bear fat, and cedar. As she prepared a smudge ceremony for us, she spoke about picking sweetgrass, "the hair of Mother Earth," and the critical need for leaving roots behind for seven generations. Each of us joined in singing with the Elder her honour song as we sat in circle together on a blanket she had brought and placed upon the deep snow.

As we critically reflect on our intentional acts of inviting a scientist and a First Nations Elder into the woods in an effort to be affected by biographies, histories, and contradictory entanglements, we realize how difficult it is to engage with common worlds thinking. Engaging Western sciences with First Nations knowledges opens up common world pedagogic possibilities. These two very different ways of entering the woods were shared through Western science and Indigenous science and ceremony. These encounters raise questions, such as, how do we deepen our sustained engagement with differing forms of relating and knowing? How might sustained engagement help us enact a caring obligation allowing us to author different kinds of relationality and ethics to better care for our common world, and the flourishing of each other, human and more than human? The challenge for us, as teacher-educators, is how to more fully engage so that we might grapple with our colonial histories, our entangled coexistences and unequal differences. How do we become "more at ease with difference than we are" (Taylor, 2013, p. 112)? 


\section{In closing: Creating spaces to think differently}

In this article, our intention has been to take up the vision of a meeting place as a means to reimagine early childhood pedagogies and thus open up possibilities for "transformative change" (Moss, 2014) in early childhood practices. Extending our theoretical reconceptualizing within meeting place encounters, we confront the discursive tenacity of developmentalism as lived within age-segregated settings, parent engagement, and humancentric nature pedagogy: The grand narrative of developmentalism played out in these ever-widening circles.

Drawing from theorizing on walls as political objects, tattooing, and common worlding, we worked to disrupt the subjugation of age-segregated children, young tattooed mothers and fathers, and the taming of children and chickadees. In so doing, we disrupt the subjugation of ourselves, as educators and researchers, as we learn to respond otherwise. Working theoretically within and across these encounters revealed bureaucratic, schooled, cultural, and colonial inheritances, provoking us to ask different questions. What if we opened the wall in-between the toddler room and the preschool room-would we see toddlers differently? What if the tattoos were a representation of deep and abiding love between the parent and child, rather than of transgression and disgrace? And, what if we invited an Elder to come with us into the woods? Could the children, and could we, listen to the forest differently?

In "Encountering the Wall," toddlers' agency and capacity to contribute to community was tangible, challenging traditional developmental expectations in profound and unexpected ways. In "Encountering Young Tattooed Parents," the shift in focus from "parent as too young to know" to "parent as knowing" inspired new possibilities for family participations based on more inclusive and equitable relationships. In "Encountering Chickadees," we were transformed by the spirituality of the Wolustoquy Elder entering the forest while being reminded of our postcolonial inheritances. We were equally and quite differently captivated by the scientist's deep knowledge of chickadees' complex biographies and how chickadee lives have become entangled with our human lives. In these "collective experimentations between theory and practice" (Olsson, 2009, p. 51), we came to different questions. In our efforts to think beyond discourses of developmentalism, we were drawn to pedagogical responses that were more "open-ended (avoiding closure), open-minded (welcoming the unexpected) and open-hearted (valuing difference)" (Moss, 2014, p. 132).

For us, this "close working relationship between research and practice" (Olsson, 2009, p. 28) reinvigorated the relationship between ourselves as scholars/teacher-educators and practicing early childhood educators. These stories helped each of us to understand how privileging particular sets of beliefs or forms of knowledge, "grand narratives" that typically reflect Western or Eurocentric values, creates power for certain groups of people while oppressing others. Echoing reconceptualist approaches, these stories evoke for us, in the words of Lourdes Diaz Soto (2000), "hope and possibility as we move toward a newly evolving, liberating 'third space,' and early childhood dreamscape of social justice and equity" (p. 198). Nonetheless, we remain keenly aware of the need for concrete support in using pedagogical dialogue to reconstruct traditional pedagogies, and of the promise of curriculum frameworks in creating productive space for dialogue. As Langford notes:

In introducing an innovation-an early learning curriculum framework-the governments of British Columbia, Saskatchewan, Ontario, New Brunswick, and Quebec have opened up new directions in early childhood care and education in Canada. To sustain the promise of these directions much is required in supports, evaluations and analyses by governments in collaboration and consultation with those most affected, early childhood educators, children and families. (Langford, 2010, p. 30)

Finally, as we continue with this work, we are reminded by Jane Bennett (2010) that "we need both critique and positive formulations of alternatives, alternatives that will themselves become the objects of later critique and reform" (p. xv). In learning to work with reconstructing particular pedagogic discourses, we understand these 
relational encounters as mutual ontological acts, and we acknowledge our need to be vigilant to the limits and possibilities of differing ways that we make sense of children, practices, and learning (MacNaughton, 1997). 


\section{References}

Ashton, E. (2014). I've got my EYE on you: Schooled readiness, standardized testing, and developmental surveillance. Canadian Children, 34(1), 3-24.

Bennett, J. (2010). Vibrant matter: A political ecology of things. Durham, NC: Duke University Press.

Corson, P. (2005) Multi-age grouping in early childhood education: An alternative discourse. In Vol. 13, Research connections Canada (pp. 93-108). Ottawa, ON: Canadian Child Care Federation.

Dahlberg, G., \& Lenz Taguchi, H. (1994). Förskola och skola-om två skilda traditioner och om visionen om en mötesplats (Preschool and school-two different traditions and the vision of a meeting place. Stockholm, Sweden: HLS Förlag.

Dahlberg, G., Moss, P., \& Pence, A. (2007). Beyond quality in early childhood education and care: Languages of evaluation (2nd ed.). London, UK: Routledge.

Deleuze, G., \& Guattari, F. (1987). A thousand plateaus: Capitalism and schizophrenia (B. Massumi, Trans.). Minneapolis, MN: University of Minnesota Press.

Diaz Soto, L. (Ed.). (2000). The politics of early childhood education. New York, NY: Peter Lang.

Edwards, S., Blaise, M., \& Hammer, M. (2009). Beyond developmentalism? Early childhood teachers' understandings of multi-age grouping in early childhood education and care. Australian Journal of Early Childhood Education, 34(4), 55-63.

Fendler, L. (2001). Educating flexible souls. In K. Hultqvist \& G. Dahlberg (Eds.), Governing the child in the new millennium (pp. 119-142). London, UK: RoutledgeFalmer.

Foucault, M. (1991). Governmentality. In G. Burchell (Ed.), The Foucault effect: Studies in governmentality (pp. 87-104). London, UK: Harvester Wheatsheaf.

Gore, J. (1998). Disciplining bodies: On the continuity of power relations in pedagogy. In T. Popekewitz \& M. Brennan (Eds.), Foucault's challenge: Discourse, knowledge, and power in education (pp. 231-255). New York, NY: Teachers College Press.

Haraway, D. (1997). Modest_Witness@Second_Millenium.FemaleMan@_meets_OncoMouse ${ }^{T M}$ : Feminism and technoscience. London, UK: Routledge.

Haraway, D. (2008). When species meet. Minneapolis: University of Minnesota Press.

Hartwich, O. M. (2009). After the wall: Twenty years on. Policy, 25(4), 8-11.

Hewes, J., Whitty, P., Aamot, B., Schaly, E., Sibbad, J., \& Ursuliak, K. (2016). Unfreezing Disney’s Frozen through playful and intentional co-authoring/co-playing. Canadian Journal of Education, 39(3), 1-25.

Heydon, R. M., \& Iannacci, L. (2008). Early childhood curricula and the depathologizing of childhood. Toronto, ON: University of Toronto Press.

Hughes, P., \& MacNaughton, G. (2000). Consensus, dissensus, or community: The politics of parent involvement in early childhood education. Contemporary Issues in Early Childhood, 1(3), 241-258. 
Jans, M. (2007). Children as citizens: Towards a contemporary notion of child participation. Childhood, 11(1), 27-44.

Johncock, W. (2012). Modifying the modifier: Body modification as social incarnation. Journal for the Theory of Social Behaviour, 42(3), 241-259.

Langford, R. (2010). Innovations in provincial early learning curriculum frameworks. Child Care Resource and Research Unit Occasional Paper No. 24. Retrieved from http://www.childcarecanada.org/sites/default/files/ op24_0.pdf

Langford, R., \& Di Santo, A. (2013). From the editors. In R. Langford \& A. Di Santo (Eds.), Leading the way: Recognizing the role of early learning lab schools in Canadian universities and colleges. Retrieved from http://www. ryerson.ca/ecs

Langman, L. (2008). Punk, porn, and resistance: Carnivalization and the body in popular culture. Current Sociology, 56(4), 657-677.

Lenz Taguchi, H. (2010). Going beyond the theory/practice divide in early childhood education: Introducing an intraactive pedagogy. Abingdon, UK: Routledge.

Lirette, P., Grove, A., \& MacDonald, J. (2012, March). Children as citizens. Paper presented at the second national early learning lab school conference "Leading the Way," Ryerson University, Toronto, Ontario.

Logue, M. E. (2006). Teachers observe to learn? Differences in social behaviour of toddlers and preschoolers in same-age and multiage groupings. Young Children, 61(3), 70-76.

MacCormack, P. (2006). The great ephemeral tattooed skin. Body and Society, 12(2), 57-82.

MacNaughton, G. (1997). Feminist praxis and the gaze in the early childhood curriculum. Gender and Education, 9(3), 317-326.

MacNaughton, G., \& Hughes, P. (2008). Doing action research in early childhood studies: A step by step guide. Maidenhead, UK: Open University Press/McGraw Hill Education.

MacNaughton, G., \& Smith, K. (2008). Engaging ethically with young children: Principles and practices for consulting justly with care. In G. MacNaughton, P. Hughes, \& K. Smith (Eds.), Young children as active citizens: Principles, policies, and pedagogies (pp. 31-43). Newcastle, Australia: Cambridge Scholars.

Major, P. (2011). Walled in: Ordinary East Germans' responses to 13 August 1961. German Politics and Society, 29(2), 8-22.

Makovichuk, L., Hewes, J., Lirette, P., \& Thomas, N. (2014). Flight: Alberta's early learning and care framework. Retrieved from http://childcareframework.com/play-participation-and-possibilities/

McAtackney, L. (2011). Peace maintenance and political messages: The significance of walls during and after the Northern Irish “Troubles.” Journal of Social Archaeology, 11(1), 77-98.

Modesti, S. (2008). Home sweet home: Tattoo parlors as postmodern spaces of agency. Western Journal of Communication, 72(3), 197-212.

Moll, L. C., Amanti, C., Neff, D., \& Gonzalez, N. (1992). Funds of knowledge for teaching: Using a qualitative 
approach to connect homes and classrooms. Theory into Practice, 31(2), 132-141.

Moss, P. (2007). Bringing politics into the nursery: Early childhood education as a democratic practice. European Early Childhood Education Research Journal, 15(1), 5-20.

Moss, P. (Ed.). (2013). Early childhood and compulsory education: Reconceptualising the relationship. Abingdon, UK: Routledge.

Moss, P. (2014). Transformative change and real utopias in early childhood education: A story of democracy, experimentation, and potentiality. Abingdon, UK: Routledge.

Nxumalo, F. (2016). Storying practices of witnessing: Refiguring quality in everyday pedagogical encounters. Contemporary Issues in Early Childhood, 17(1), 39-53.

Olsson, L. M. (2009). Movement and experimentation in young children's learning: Deleuze and Guattari in early childhood education. London, UK: Routledge.

Pacini-Ketchabaw, V. (Ed.) (2010). Flows, rhythms, and intensities of early childhood education curriculum. NewYork, NY: Peter Lang.

Pacini-Ketchabaw, V., Nxumalo, F., Kocher, L., Elliot, E., \& Sanchez, A. (2015). Journeys: Reconceptualizing early childhood practices through pedagogical narration. Toronto, ON: University of Toronto Press.

Pacini-Ketchbaw, V., \& Pence, A. (2011). The postmodern curriculum: Making space for historically and politically situated understandings. Australasian Journal of Early Childhood, 36(1), 4-8.

Pacini-Ketchabaw, V., \& Prochner, L. (Eds.). (2013). Resituating Canadian early childhood education. New York, NY: Peter Lang.

Ritchie, J. (2012). Early childhood education as a site of ecocentric counter-colonial endeavour in Aotearoa New Zealand. Contemporary Issues in Early Childhood, 13(2), 86-98.

Rose, D. B. (2011). Wild dog dreaming: Love and extinction. Charlottesville, VA: University of Virginia Press.

Rose, D. B., van Dooren, T., Chrulew, S., Cooke, S., Kearnes, M., \& O’Gorman, E. (2012). Thinking through the environment, unsettling the humanities. Environmental Humanities, 1(1), 1-5. Retrieved from https:// environmentalhumanities.org/arch/vol1/EH1.1.pdf

Rose, S. (2013). Putting narrative documentation to work: A search for educational abundance (Unpublished doctoral dissertation). University of New Brunswick, Fredericton.

Shoveller, J. A., \& Johnson, J. L. (2006). Risky groups, risky behaviour, and risky persons: Dominating discourses on youth sexual health. Critical Public Health, 16(1), 47-60.

Smith, D. (1987). The everyday world as problematic: A feminist sociology. Boston, MA: Northeastern University Press.

Taylor, A. (2013). Reconfiguring the natures of childhood. London, UK: Routledge.

Taylor, A., \& Pacini-Ketchabaw, V. (2015). Learning with children, ants, and worms in the Anthropocene: Towards a common world pedagogy of multispecies vulnerability. Pedagogy, Culture \& Society, 23(4), 507-529. 
Vandenbroeck, M., De Stercke, N., \& Gobeyn, H. (2013). What if the rich child has poor parents? The relationship from a Flemish perspective. In P. Moss (Ed.), Early childhood and compulsory education (pp. 174-191). Abingdon, UK: Routledge.

Vandenbroek, M., \& Peeters, J. (2014). Democratic experimentation in early childhood education. In G. Biesta, M. de Bie, \& D. Wildemeersch (Eds.), Civic learning, democratic citizenship, and the public sphere (pp. 151165). The Netherlands: Springer. Retrieved from http://www.childcarecanada.org/documents/researchpolicypractice/14/10/democratic-experimentation-early-childhood-education

1 As the creation of curriculum frameworks for our youngest children continues, curricular work in one province or territory informs curricular work within other provinces and territories. In addition, pan-Canadian forums such as the Association of Canadian Deans of Education, the Council of Ministers of Education, national and international institutes and forums, and the long-standing contributions of the Canadian Childcare Resource and Research Unit also inform national/provincial and territorial discussions. Recent changes to the Child Tax Benefit and the Federal-Territorial-Provincial bi-lateral agreements keep ECE in the foreground. 